\title{
Depreciation of Capital due to Natural Disaster and Adjusted Net Domestic Product
}

\author{
June 2020 \\ Corresponding Author \\ Amarendra Das \\ Reader-F \\ Dasarathi Padhan \\ PhD Scholar \\ Chinmayee Sahoo \\ $\mathrm{PhD}$ Scholar \\ Email: amarendra@niser.ac.in \\ School of Humanities and Social Sciences \\ National Institute of Science Education and Research Bhubaneswar \\ Jatnai, Khordha,-752050, Odisha, India \\ Homi Bhabha National Institute Anushaktinagar, Mumbai - 400094, India
}

\begin{abstract}
The conventional measures of national income accounting do not account for the depreciation of physical capital caused by natural disasters. Some national and subnational economies face natural disasters more frequently than the others. Capital formation through continuous investment in physical capital is a prerequisite for fast economic growth and poverty reduction. Therefore, frequent occurrence of natural disasters may deplete the physical capital base (such as public infrastructure, private enterprises etc.) and hence may reduce the capability of individuals and states to improve their living standard. Therefore, NDP calculation should also take into account the depreciation of physical capital caused by natural disasters.

To our knowledge, systematic studies on the economic accounting of loss due to natural disasters in Indian context, are limited. This paper tries to account for the economic loss due to natural disasters, as the depreciation of capital and provide the adjusted estimate of NDP. Systematic data on economic loss due to natural disasters are limited for all Indian states. Therefore, this paper provides a methodological framework for accounting for the depreciation of the capital due to natural disasters for all Indian states and provides an approximate estimate of adjusted NDP for all Indian states. Due to availability of systematic data on the economic loss due to natural disasters, time series estimate of adjusted NDP are provided for Odisha state which experiences maximum climatic natural disasters. Calculation of adjusted NDP will be very much useful for fiscal transfer from Union to States and other economic policy making.
\end{abstract}

\section{Key Words}

Adjusted NDP, Natural Disaster, Consumption of Fixed Capital, Depreciation 


\section{Introduction}

In last two decades attempts are being made to compute a better metrics to measure the national income that accounts for the environmental resources and costs. The conventional measures of national income accounting do not take into consideration the benefits environmental/natural resources and the cost of their degradations. Therefore, economists have been trying to include the depletion of natural resources as depreciation of natural capital and measure a modified Net Domestic Product. This adjusted NDP is Gross Domestic Product less the depreciation of physical capital and natural capital. However this measure also does not account for the depreciation of physical capital caused by natural disasters. Some national and sub-national economies face natural disasters more frequently than others. Capital accumulation through continuous investment and physical capital and human capital are prerequisites for improving the living standard. Therefore, frequent occurrence of natural disasters may deplete the physical capital base (such as public infrastructure, private enterprises etc.) and reduce the fiscal space to invest in human capital (health and education). As a result of this the capability of individuals and states to improve the living standard may decline or at least not improve. Therefore, NDP calculation should also take into account the depreciation of physical capital caused by natural disasters.

Attempts have been made in other country context to measure the full economic cost of disaster (Rasmussen, 2004; Gaddis et al.,2007; Noy 2009; Raddatz, 2009; Shabnam, 2014), and link the effects of disasters on economic growth (Hallegatte and Dumas 2009). Similarly studies (Raddatz, 2009) have attempted to differentiate the macro economic effects of climatic and other disasters. Other studies have compared the costs of disasters across geographical areas and income levels and to answer structural and policy related aspects of costs due to disasters (Noy, 2008). In Indian context Das (2012) has attempted to understand the role of natural ecosystems and socio-economic factors in the vulnerability of coastal villages to cyclone and storm surge.

\subsection{UN Framework for National Income Accounting}

United Nations System of National Accounts (UNSNA, hereafter) provides a systematic and uniform method of calculation of the economic activities which help us in comparing economies throughout world. GDP has been used as one of the welfare measurements. But how far GDP reflects welfare is a matter of question. What are the components that enter into the measurement of GDP should also be discussed. It has been found that the contributions of environment to the economic growth and human welfare have been ignored in national account system. Environmental costs resulting from human activities and natural disasters have not been accounted. National Accounts of a country which are measures of economic activities should incorporate the environmental benefits and cost. The System of National Accounts of United Nations prevalent and followed across the economies does not integrate the environmental aspects of an economy. To consider the value of environment and environmental costs in accounting system of the economy, United Nations developed a framework for all countries called Integrated Environmental and Economic Accounting (SEEA) in 1993. The conventional framework for estimation of national accounts may lead to overestimation or underestimation of GDP. In National Account system of India, environmental goods and services like productivity of land, biodiversity are not included. GDP is not adjusted by environmental costs like depletion of natural resources, pollution, deforestation, etc. 


\subsection{Need for Changes in National Account System}

Impact of natural disasters has not been included in National Account System of India due to non-availability of complete data. Natural Disasters have bearings on economy. Disasters affect economic system in many ways. They have impacts on production system, consumption pattern, employment, saving, distribution, etc. One of the limitations of conventional GDP measurement is non-inclusion of costs inflicted by natural disasters (Dasgupata, 2013).

Government has to bear huge amount of cost in terms of compensation, rebuilding of damaged infrastructure, etc. Economic damage of natural disasters is enormous. This amount can be used for the increase of welfare of the people, if natural disasters are prevented to occur. Natural calamities impose fiscal burden on the economy. But the accounting system in India completely ignores this huge cost in the process of calculating Net Domestic Product. The method followed by Central Statistical Organisation, India is as follows:

\subsection{Income Accounting in India}

\subsubsection{The Production Identities}

Gross Value Added (GVA) at factor cost= Output - Intermediate consumption

Gross Domestic Product (GDP) at factor cost $=$ Sum of GVA at factor cost

GDP at Market Prices $=$ GDP at factor cost

$+($ taxes - subsidies) on production and export/import

$=$ final consumption expenditures

+ Changes in inventories

+ Gross fixed capital formation

+ Acquisition less disposals of valuables

+ Exports of goods and services

- Imports of goods and services

$=$ Compensation of employees

+ Operating surplus/ mixed income

+ Consumption of fixed capital (CFC)

$+($ taxes - subsidies) on production and export/import

Net Domestic Product at factor cost $/$ market price $=$ GDP at factor cost $/$ market price - CFC

\subsubsection{Saving and Investment Identities}

Net Saving + net capital transfers receivable $=$ Gross fixed capital formation $-\mathrm{CFC}$

+ Changes in Inventories

and

+ Acquisitions less disposals of valuables 


$$
\begin{aligned}
& \text { Non- produced non-financial assets } \\
& \text { + net lending / net borrowing }
\end{aligned}
$$

Net lending $(+)$ /borrowing $(-)=$ net acquisitions of financial assets less net incurrence of financial liabilities

\subsubsection{Capital Formation and Consumption of Capital}

Gross Capital Formation (GCF) refers to the aggregate of gross additions to fixed assets (fixed capital formation), increase in stocks of inventories or change in stocks (CIS) and valuables. Gross Fixed Capital Formation (GFCF) comprises two main components, (i) construction, and (ii) machinery and equipment. Only new 'Construction' forms part of GFCF from construction. All repairing and maintenance works won't be accounted in GFCF. Natural Calamities such as flood and cyclone cause damages to infrastructure. Public buildings, roads, canals, etc. get destroyed when severe cyclone or flood or earthquake occurs. Government spends a huge amount of money in repairing those damaged infrastructure resulting in extra fiscal burden on economy. But this spending does not appear in our national accounts.

Consumption of Fixed Capital is defined as the decline, during the course of the accounting period, in the current value of the stock of fixed assets owned and used by a producer as a result of physical deterioration, normal obsolescence or normal accidental damage. It excludes the value of fixed assets destroyed by acts of war or exceptional events such as major natural disasters which occur very infrequently. But the question arises, what if the natural calamities occur frequently in a country and the costs are enormous. What could be the possible economic implications of the damages of the physical capital on capital stock and income generation? Can we ignore the huge costs borne due to calamities in our national accounts?

We can see in the above method followed by CSO, India only the consumption of fixed capital has been taken into account. Depletion of natural capital is being ignored in the measurement process. Observing this limitation in the methodology, United Nations has developed a new framework named System of Environmental and Economic Accounting which attempts to take environmental costs and benefits into consideration. In this new method, emphasis has been given to depreciation of natural capital.

\section{Literature on Natural Disaster, Economic growth and Capital}

Macroeconomic consequences of disasters depend upon the economic structure or structural changes of an economy and stage of development. Studies show that the US experienced the highest number of natural disasters as compared to any other country. In the 506 natural disasters that affected the US during 1974-2003 killed 4.5 million people. On the other hand, developing countries like India and Bangladesh experienced 303 and 174 disaster respectively, but the number of people killed by this disaster were 1832 million and 375 million respectively over the same period. (Guha-Sapir et al., 2004)

In case of Dominica and Bangladesh, the vulnerability has changed because of structural change i.e. declining share of agriculture to total GDP of the economy. Less developed countries are more vulnerable to natural disasters. Natural disasters have significant impacts on budgetary allocation. In Bangladesh reallocation happens because of overestimation of 
revenue and under estimation of expenditure due to disasters. Post disaster tax affects the level of revenue. Disaster can influence the timing of tax. The availability of good-quality, trustworthy data is a necessary for effective management of natural disaster risk (Benson and Clay, 2004).

Hallegatte, Hourcade, and Dumas (2007) explore the effects of short term shocks in the long term growth models used in climate change assessments. Non-equilibrium dynamic Model (NEDyM) is used to capture unbalanced growth pathways. By redesigning the Solow model the study compares economic consequences of a given climate impact falling on economies. The study finds that production losses due to extreme events depend on strong non linearity in the characteristics of the distribution and on the capacity to conduct reconstruction after disaster. In case of high intensity shocks with a certain frequencies and probability distribution, the ultimate costs may be higher than the suggested mean value of impacts. Noy (2008) compares the costs of disasters across geographical areas and income levels and tries to address the question of structural and policy related aspects of costs due to disasters. It calculates the disaster measures based on cost measure and onset month. Results of the study show that there is no correlation between disaster population variables and GDP growth. Negative relation exists between property damage and GDP growth. Property cost has short term impact. Human cost impact is long term in nature. Large disasters have more adverse affects. Because of output dynamic developing countries face more impact than developed countries. Small economies are more vulnerable because they are less diversified.

Hallegatte and Dumas (2009) examine the productivity effect in post disaster period. The study integrates simple modelling of technical change and NEDyM to investigate the productivity effect. In the following year of the disaster, perfect productivity effect leads to small reduction in productivity growth. After one year due to investment in reconstruction productivity growth rises and it brings positive outcome. With perfect productivity effect, production level in disaster scenario can be higher than the production level in a scenario without disaster. But we can't say disasters have absolute positive impact on economy. Imperfect productivity effect increases the negative consequences of disasters. Productivity effect does able to make disaster a positive event. Disasters have influence on short term growth rate and long term production level. Disasters can't influence the long term growth rate.

Das (2016) discusses the debate on the positive and negative impacts of natural calamities on economy. Natural calamities can also have positive externalities. Disasters can lead to increase in productivity. It is argued that because of the occurrence of calamities old infrastructures are replaced by new ones and innovations happen which lead to increase in productivity. On the other hand, huge damages due to natural calamities can lead to economic backwardness. Frequent occurrence of natural disasters can push the economy into poverty trap. She finds, in her study in the case of Odisha, that severe droughts and floods/cyclones have adverse impacts on the state GSDP.

Jonkman, Bockarjova, Kok and Bernardini (2008) present and demonstrate the integrated hydrodynamic and economic model developed in the Netherlands to predict and assess the damage due to catastrophe flooding. Damages to residences, capital assets, agricultural land, environment, etc. are direct damages. Indirect losses are the societal disruption, psychological traumas, temporary housing of evacuees etc. Total damage is 24 billion euro which is $6.5 \%$ of GDP of the year $2000.70 \%$ of the total damages are the direct physical damages to residential property. Share of direct damages to businesses, commercial and public property and agriculture are $11 \%, 10 \%$ and $8 \%$ respectively. 
Cuaresma(2009) tries to quantify the effect of natural disaster risk on investment in education. The study uses Bayesian Model Averaging to obtain estimates of effect of disaster risks on secondary school enrolment rate. Without controlling other variables which affect educational attainment it is found that there is a weak positive relationship between disaster risk and secondary school enrolment. After controlling other variables, there exists a negative long run effect of geological natural disaster risk on secondary school enrolment rates. Long run impact is homogenous across countries and do not depend on income or the degree of human capital accumulation in the country. Impact is independent of political regime.

Raddatz (2009) aims to quantify the macroeconomic consequences of climatic and other disasters in developing countries. This study discusses three categories of disasters such as climatic (flood, draught and windstorm etc.), geological (earthquake, landslide and volcano eruption, etc) and residual group (famine, epidemic, insect plague, etc. It is found that a climatic disaster reduces per capita GDP by 0.6 percent. Geological disasters do not have significant impact on output of the economy. Due to occurrence of other types of disaster, 2 percent output loss happens. Larger states are affected more than small states. Low income countries respond more strongly to climatic disasters. In these countries climatic disaster reduces 1pecent per capita output. For middle and high income countries, cumulative per capita losses are $0.5 \%$ and $0.25 \%$ respectively. There is no correlation between indebtedness and impact of natural disasters.

Hallegate and Przyluski (2010) examine the important mechanisms that explain and determine the cost of large-scale disasters. It is argued that to define the cost of a disaster as the relevant cost is impossible. Secondly, there are large uncertainties on indirect disaster costs because of insufficient data and inadequate methodologies.

Das (2012) appraises the probability of expected human fatality (death risk) due to severe cyclone and storm surge for the villages associated with one of the most cyclones prone districts of India. This research is based on the conventional risk hazard models that link both the risk and vulnerability together. For estimating human deaths the study uses both the Logit and Poisson specification. It is found that six variables are impacting the death probability of villages significantly under both Logit and Poisson specifications. 112-132 villages qualify as least vulnerable with a death probability of less than 0.1 . 82-72 villages are moderately vulnerable with a death probability ranging between 0.1 and 0.3 . 34-37 villages rated as vulnerable with a death probability in between $0.3-0.5$. And 34-21 villages have high vulnerability with a death probability of greater than 0.5 . 52 villages witnessed human casualties, but the death probability shows that around 130-150 villages have more than a 10 per cent chance of witnessing deaths.

Shabnam (2014) aims to understand the effects of natural disasters on economic growth by taking into account some significant economic indicators. The study estimates the impact of floods with regard to death toll and the total number of people affected by floods. The study employed a large panel dataset from 1960 to 2010 of 187 countries and tracks the relationship between floods and economic growth rate formulated by panel data analysis. Total number of affected people in floods significantly affects the GDP per capita growth rate whereas the death toll in floods has no substantial effect on annual GDP per capita growth. Floods naturally create havoc in people's livelihoods rather than claiming a high human death toll.

Parida (2019) has examined the consequences of economic development and the role of political alignment on the human death and damages due to floods in India for the time 
period 1980-2011. He found that economic development reduces the fatalities and damage due to floods in India. He also observed that along with economic development better political coordination between the national and sub-national government is essential to mitigate the impact of floods. However, with district level analysis conducted for Odisha state Parida et al (2020) found that economic development (proxied by per capita income) is not adequate to minimize fatalities from natural disasters. They also argue that better disaster adaptation measures such as better medical facilities, adequate road infrastructure, higher primary enrolment, village electrification, forest cover, and financial accessibility help in mitigating disaster fatalities to some extent.

Parikh and Parikh (1997) based on SEEA approach give the definition of Green Net National product as follows:

Net National Product $=$ Value of consumption of normal goods and services

+ Value of production of nature collected

+ Value of environmental amenities provided by

Environmental resource stocks

+ Value of leisure enjoyed

+ Value of net additions to production capital

+ Value of net additions to natural capital stock

+ Value of additions to stock of defensive capital

Adjusted National Savings (ANS) can be calculated by the following formula:

ANS $=$ Net Saving + Education Expenditure $-($ Energy depletion + Mineral depletion+ Damage from carbon dioxide)

Most of the works on natural disasters have dealt with the impacts of disasters on economic growth, human capital, fiscal burden, etc. We did not find any work which deals with the relation between the impacts of natural disasters and national account of the economy. The central question that arises here is, what would be the change in national accounts if economic losses due to natural disasters are incorporated in the measurement of NDP and NSDP. Hence, this work attempts to fulfil the following objectives:

\section{Objectives}

The objectives of our research paper are twofold:

(1) To account for the economic loss due to natural disasters for Indian states

(2) To provide a framework for estimating Natural Disaster Adjusted Net Domestic Product and compute the same for Indian States.

\section{Methodology and Data}

The paper provides a conceptual framework for incorporating the depreciation of physical capital due to natural disaster in the Net Domestic Product calculation. Further secondary 
data have been compiled to assess the economic cost of natural disaster. Data have been collected from several sources namely Central Water Commission, Reports of Finance Commission of India, Reports of Odisha state Disaster Management Authority and Special Relief Commissioner and National Institute of Disaster Management.

\section{Framework for Natural Disaster Adjusted NSDP}

In conventional method of calculation of National Accounts the depreciation of physical capital is deducted from GDP to arrive at NDP. But this depreciation of capital does not consider the destruction of physical capital due to natural disasters. Natural disasters like flood, earthquake, cyclone, etc. cause heavy damage to the physical infrastructures of an economy. Industries, school buildings, hospitals, residential houses and other constructions get devastated by natural disasters. Hence, productive capital base of the economy dwindles. Reduction in the capital base of a country or a state reduces the production capability of both state and individual. Reduction in welfare of the people follows. In post-disaster period state has to spend a lot of resources for rebuilding the destroyed or damaged capital base. These expenditures incurred on repairing the damaged and destroyed capital base could have been used to create new physical capital or invested in the formation of human capital or invested in other poverty alleviating schemes. Therefore the investment for reconstruction is not contributing to the increase in capital base (physical and human capital) of the economy which was there in pre-disaster period. Rather state has to spend a lot to maintain the capital base existed before occurrence of the disaster. Hence these expenditures should be treated as the depreciation to the existed physical capital rather than entering them in the capital account.

Economists use Domar (1946) equation to forecast the growth rate if the rate of investment is known. The same equation is also used in computing the required investment for achieving a certain level of growth. The equation is written as $G=\frac{I}{k}$ where $\mathrm{G}$ refers to growth rate of national output i.e. GDP or at state level GSDP; $I$ is level of investment or in case of $S=I$ this is also rate of saving and $k$ is capital output ratio. Therefore, Growth rate of a state depends positively on the rate of productive investment.

When net investment declines, level of national income decreases. Given this relationship between investment and national income, when there is occurrence of natural disaster the real investment which would help in increasing the level of capital stock does not grow resulting in a reduction of national income.

All investments can be classified into two categories: investment for new productive capital $I_{p}$ and investment for reconstruction $I_{r}$.

Total Investment $I=I_{p}+I_{r}$

$I_{n}$ increases the Gross capital formation of an economy in increasing production and capital in the absence of disasters whereas Investment for reconstruction helps in bringing back the capital to the previous level. (Hallegatte and Dumas, 2009).

Usually the Gross Capital Formation is calculated using the perpetual inventory method given as follows

$$
K_{t-1}=K_{t-2}+I_{t-1}
$$




$$
\begin{gathered}
K_{t}=K_{t-1}+I_{t} \\
K_{t+1}=K_{t}+I_{t+1} \\
K_{n}=K_{n-1}+I_{n}
\end{gathered}
$$

If $I=I_{p}+I_{r}$, then capital accumulation in time period $\mathrm{n}$ will depend upon only $I_{p}$ not $I_{r}$. In this case a state having higher expenditure on $I_{r}$ will have lower capital formation and hence lower growth rates.

Effect of destruction of capital or infrastructure due to natural disaster may vary across economies and households. Possibility of the destruction of infrastructure in terms of money value could be high in case of developed countries as compared to underdeveloped ones. Reconstruction cost will also vary accordingly. Recovering capacity of the economies also depends upon the state of the economy. This logic can be applied to household level as well. Economic condition of households determines the amount cost borne and the capacity to bounce back to normal standard of life. Reconstruction investment plays a pivotal role in state economy and household economy at a disaster period.

\section{Analysis}

Between 1891 and 2002 a total number of 356 major tropical cyclones have hit the Indian coast (See table 1). Out of these, east coast has faced maximum number of (308) cyclones and west coast only 48 cyclones. In the east coast, maximum number of cyclones have been faced by Odisha, followed by it neighbouring states namely Andhra Pradesh and West Bengal. Table 1 presents the major tropical cyclones in the Indian Coast between 1891 and 2001.

Table 1: Major Tropical Cyclones in the Indian Coast between 1891 and 2002

\begin{tabular}{|l|l|l|l|}
\hline West Coast & East Coast \\
\hline Kerala & 3 & West Bengal & 69 \\
\hline Karnataka & 2 & Odisha & 98 \\
\hline Maharashtra & 13 & Andhra Pradesh & 79 \\
\hline Goa & 2 & Tamil Nadu & 54 \\
\hline Gujarat & 28 & Puduchery & 8 \\
\hline Total & 48 & Total & 308 \\
\hline \multicolumn{4}{|l|}{ Source: NCRMP (2019) } \\
\hline
\end{tabular}

\subsection{Cost of Natural Disasters}

Natural disasters cause loss of life, loss of individual property such as crop loss, damage of house, assets, livestock, loss of livelihood; damage of public property such as roads, bridges, disruption of power supply and collapse of power supply systems, school and college buildings, fear of outbreak of epidemics and so on. For this reason government needs to prepare for mitigating the disasters through pre disaster evacuation, information and communication for awareness generation; post disaster relief, reconstruction of private and public properties and so on. It is therefore important to calculate the full cost of natural disaster to know the economic implications. The government of India has enlisted the following 12 disasters for estimation of economic loss. Table 2 describes the list of 12 natural disasters for allocating disaster relief funds. 


\begin{tabular}{|l|l|}
\hline \multicolumn{2}{|l|}{ Table 2: List of Disasters recognized by NDRF } \\
\hline S1 No & List of Disasters \\
\hline 1 & Flood \\
\hline 2 & Drought \\
\hline 3 & Fire \\
\hline 4 & Hailstorn \\
\hline 5 & Cyclone \\
\hline 6 & Earthquake \\
\hline 7 & Tsunami \\
\hline 8 & Landslide \\
\hline 9 & Avalanche \\
\hline 10 & Cloud Burst \\
\hline 11 & Pest Attack \\
\hline 12 & Cold Wave/Frost \\
\hline
\end{tabular}

Systematic data are not available in public domain for researchers to carry out in depth analysis on the cost of natural disaster. Informations are available for specific disasters and for a few states only. Very recently some data have been generated by the Forecast Monitoring Directorate, Central Water Commission, Government of India (2018) on the economic damage caused by the floods in all states of India. Table 3 presents the total cost of floods in India from 1953 to 2016.

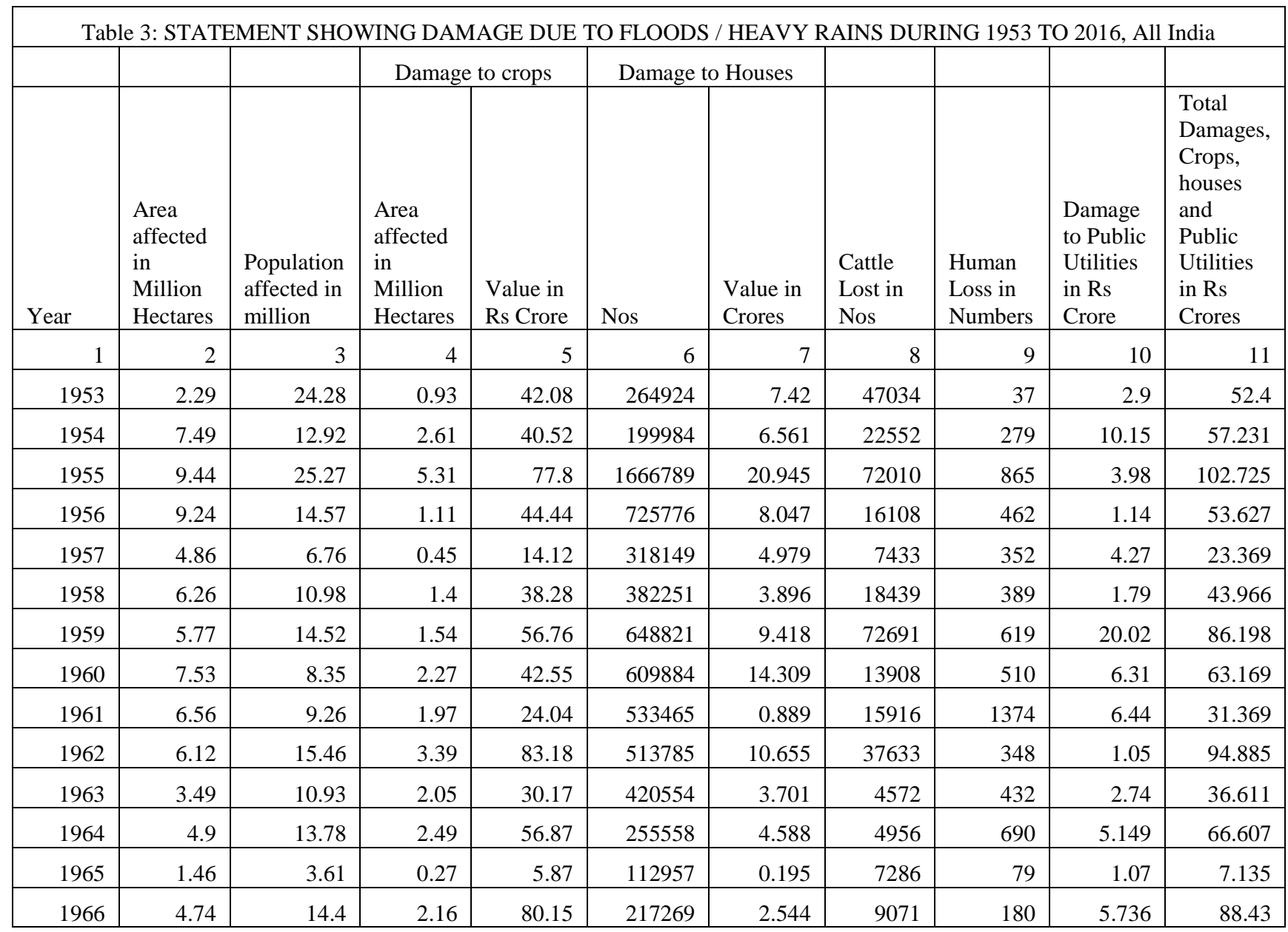




\begin{tabular}{|c|c|c|c|c|c|c|c|c|c|c|}
\hline 1967 & 7.12 & 20.46 & 3.27 & 133.31 & 567995 & 14.264 & 5827 & 355 & 7.857 & 155.431 \\
\hline 1968 & 7.15 & 21.17 & 2.62 & 144.61 & 682704 & 41.112 & 130305 & 3497 & 25.373 & 211.095 \\
\hline 1969 & 6.2 & 33.22 & 2.91 & 281.9 & 1268660 & 54.423 & 270328 & 1408 & 68.112 & 404.435 \\
\hline 1970 & 8.46 & 31.83 & 4.91 & 162.78 & 1434030 & 48.606 & 19198 & 1076 & 76.441 & 287.827 \\
\hline 1971 & 13.25 & 59.74 & 6.24 & 423.13 & 2428031 & 80.241 & 12866 & 994 & 129.113 & 632.484 \\
\hline 1972 & 4.1 & 26.69 & 2.45 & 98.56 & 897301 & 12.46 & 58231 & 544 & 47.174 & 158.194 \\
\hline 1973 & 11.79 & 64.08 & 3.73 & 428.03 & 869797 & 52.482 & 261016 & 1349 & 88.489 & 569.001 \\
\hline 1974 & 6.7 & 29.45 & 3.33 & 411.64 & 746709 & 72.434 & 16846 & 387 & 84.942 & 569.016 \\
\hline 1975 & 6.17 & 31.36 & 3.85 & 271.49 & 803705 & 34.097 & 17345 & 686 & 166.05 & 471.637 \\
\hline 1976 & 11.91 & 50.46 & 6.04 & 595.03 & 1745501 & 92.16 & 80062 & 1373 & 201.495 & 888.685 \\
\hline 1977 & 11.46 & 49.43 & 6.84 & 720.61 & 1661625 & 152.29 & 556326 & 11316 & 328.948 & 1201.848 \\
\hline 1978 & 17.5 & 70.45 & 9.96 & 911.09 & 3507542 & 167.574 & 239174 & 3396 & 376.1 & 1454.764 \\
\hline 1979 & 3.99 & 19.52 & 2.17 & 169.97 & 1328712 & 210.606 & 618248 & 3637 & 233.627 & 614.203 \\
\hline 1980 & 11.46 & 54.12 & 5.55 & 366.37 & 2533142 & 170.851 & 59173 & 1913 & 303.283 & 840.504 \\
\hline 1981 & 6.12 & 32.49 & 3.27 & 524.56 & 912557 & 159.63 & 82248 & 1376 & 512.314 & 1196.504 \\
\hline 1982 & 8.87 & 56.01 & 5 & 589.4 & 2397365 & 383.869 & 246750 & 1573 & 671.607 & 1644.876 \\
\hline 1983 & 9.02 & 61.03 & 3.29 & 1285.85 & 2393722 & 332.327 & 153095 & 2378 & 873.429 & 2491.606 \\
\hline 1984 & 10.71 & 54.55 & 5.19 & 906.09 & 1763603 & 181.308 & 141314 & 1661 & 818.164 & 1905.562 \\
\hline 1985 & 8.38 & 59.59 & 4.65 & 1425.37 & 2449878 & 583.855 & 43008 & 1804 & 2050.043 & 4059.268 \\
\hline 1986 & 8.81 & 55.5 & 4.58 & 1231.58 & 2049277 & 534.41 & 60450 & 1200 & 1982.535 & 3748.525 \\
\hline 1987 & 8.89 & 48.34 & 4.94 & 1154.64 & 2919380 & 464.49 & 128638 & 1835 & 950.59 & 2569.72 \\
\hline 1988 & 16.29 & 59.55 & 10.15 & 2510.9 & 2276533 & 741.6 & 150996 & 4252 & 1377.8 & 4630.3 \\
\hline 1989 & 8.06 & 34.15 & 3.01 & 956.74 & 782340 & 149.82 & 75176 & 1718 & 1298.77 & 2405.33 \\
\hline 1990 & 9.303 & 40.259 & 3.179 & 695.61 & 1019930 & 213.733 & 134154 & 1855 & 455.266 & 1708.92 \\
\hline 1991 & 6.357 & 33.889 & 2.698 & 579.015 & 1134410 & 180.421 & 41090 & 1187 & 728.893 & 1488.329 \\
\hline 1992 & 2.645 & 19.256 & 1.748 & 1027.578 & 687489 & 306.284 & 78669 & 1533 & 2010.67 & 3344.532 \\
\hline 1993 & 11.439 & 30.409 & 3.206 & 1308.627 & 1926049 & 528.324 & 211193 & 2864 & 1445.534 & 3282.485 \\
\hline 1994 & 4.805 & 27.548 & 3.963 & 888.622 & 914664 & 165.206 & 52315 & 2078 & 740.762 & 1794.59 \\
\hline 1995 & 5.245 & 35.932 & 3.245 & 1714.787 & 2001898 & 1307.894 & 62438 & 1814 & 679.627 & 3702.308 \\
\hline 1996 & 8.049 & 44.729 & 3.827 & 1124.491 & 726799 & 176.589 & 73208 & 1803 & 861.393 & 3005.743 \\
\hline 1997 & 4.569 & 29.663 & 2.258 & 692.743 & 505128 & 152.504 & 27754 & 1402 & 1985.934 & 2831.181 \\
\hline 1998 & 10.845 & 47.435 & 7.495 & 2594.167 & 1932874 & 1108.783 & 107098 & 2889 & 5157.771 & 8860.721 \\
\hline 1999 & 7.765 & 27.993 & 1.753 & 1850.873 & 1613260 & 1299.057 & 91289 & 745 & 462.83 & 3612.76 \\
\hline 2000 & 5.382 & 45.013 & 3.58 & 4246.622 & 2628855 & 680.943 & 123252 & 2606 & 3936.979 & 8864.544 \\
\hline 2001 & 6.175 & 26.463 & 3.964 & 688.481 & 716187 & 816.474 & 32704 & 1444 & 5604.461 & 7109.416 \\
\hline 2002 & 7.09 & 26.323 & 2.194 & 913.092 & 762492 & 599.368 & 21533 & 1001 & 1062.083 & 2574.543 \\
\hline 2003 & 6.12 & 43.201 & 4.268 & 7307.23 & 775379 & 756.481 & 15161 & 2166 & 3262.154 & 11325.87 \\
\hline 2004 & 5.314 & 43.725 & 2.888 & 778.694 & 1664388 & 879.601 & 134106 & 1813 & 1656.09 & 3314.385 \\
\hline 2005 & 12.562 & 22.925 & 12.299 & 2370.923 & 715749 & 380.531 & 119674 & 1455 & 4688.219 & 7439.672 \\
\hline 2006 & 1.096 & 25.224 & 1.822 & 2850.668 & 1497428 & 3636.848 & 266945 & 1431 & 13303.93 & 19790.92 \\
\hline 2007 & 7.145 & 41.402 & 8.795 & 3121.532 & 3280233 & 2113.108 & 89337 & 3389 & 8049.037 & 13283.68 \\
\hline 2008 & 3.427 & 29.91 & 3.186 & 3401.563 & 1566809 & 1141.891 & 101780 & 2876 & 5046.481 & 9589.935 \\
\hline 2009 & 3.844 & 29.537 & 3.592 & 4232.609 & 1235628 & 10809.8 & 63383 & 1513 & 17509.35 & 32551.76 \\
\hline 2010 & 2.624 & 18.297 & 4.994 & 5887.38 & 293830 & 875.952 & 39706 & 1582 & 12757.25 & 19520.59 \\
\hline
\end{tabular}




\begin{tabular}{|r|r|r|r|r|r|r|r|r|r|r|}
\hline 2011 & 1.895 & 15.973 & 2.718 & 1393.847 & 1152518 & 410.475 & 35982 & 1761 & 6053.57 & 7857.892 \\
\hline 2012 & 2.141 & 14.689 & 1.95 & 1534.108 & 174526 & 240.572 & 31558 & 933 & 9169.968 & 10944.65 \\
\hline 2013 & 7.546 & 25.927 & 7.484 & 6378.078 & 699525 & 2032.83 & 163958 & 2180 & 38937.84 & 47348.75 \\
\hline 2014 & 12.775 & 26.505 & 8.007 & 7255.151 & 311325 & 581.978 & 60196 & 1968 & 7710.948 & 15548.08 \\
\hline 2015 & 4.478 & 33.203 & 3.374 & 17043.95 & 3959191 & 8046.969 & 45597 & 1420 & 32200.18 & 57291.1 \\
\hline 2016 & 7.065 & 26.555 & 6.658 & 4052.723 & 278240 & 114.676 & 22367 & 1420 & 1507.926 & 5675.325 \\
\hline TOTAL & 460.26 & 2040.266 & 251.047 & 102273.6 & 79465079 & 44390.34 & 6022676 & 105472 & 199730.2 & 347581.2 \\
\hline AVG & 7.192 & 31.879 & 3.923 & 1598.026 & 1241642 & 693.599 & 94104 & 1648 & 3120.784 & 5430.956 \\
\hline MAX & 17.5 & 70.45 & 12.299 & 17043.95 & 3959191 & 10809.8 & 618248 & 11316 & 38937.84 & 57291.1 \\
\hline (YEAR) & 1978 & 1978 & 2005 & 2015 & 2015 & 2009 & 1979 & 1977 & 2013 & 2015 \\
\hline SOUr & & & & & & &
\end{tabular}

Source: Flood Forecast Monitoring Directorate, Central Water Commission, Government of India (2018) State Wies Flood Damage Statistics

Figure 1 presents the Consumption of Fixed Capital as percentage of GDP and aggregate economic loss due to floods in India. The objective behind plotting this figures is to know see the trends of both indicators. For this purpose, we have used the CFC and GDP at market price in 2004-05 constant prices. The economic losses due to floods are given in constant prices. We used the GDP deflator to bring it to 2004-05 constant prices and then calculated the economic losses due to floods as a percentage of GDP. Between 1950-51 and 2012-13, the rate of CFC as a percentage of GDP varied between eight percent to a little above 12 per cent. The economic loss due to floods as a per cent of GDP varied from $0.4 \%$ to $1.4 \%$ during 1953-2013. If we consider all the economic loss due to floods as depreciation of capital, the total consumption of capital for the country would increase by $0.4 \%$ to $1.4 \%$. We have shown this in figure 1.

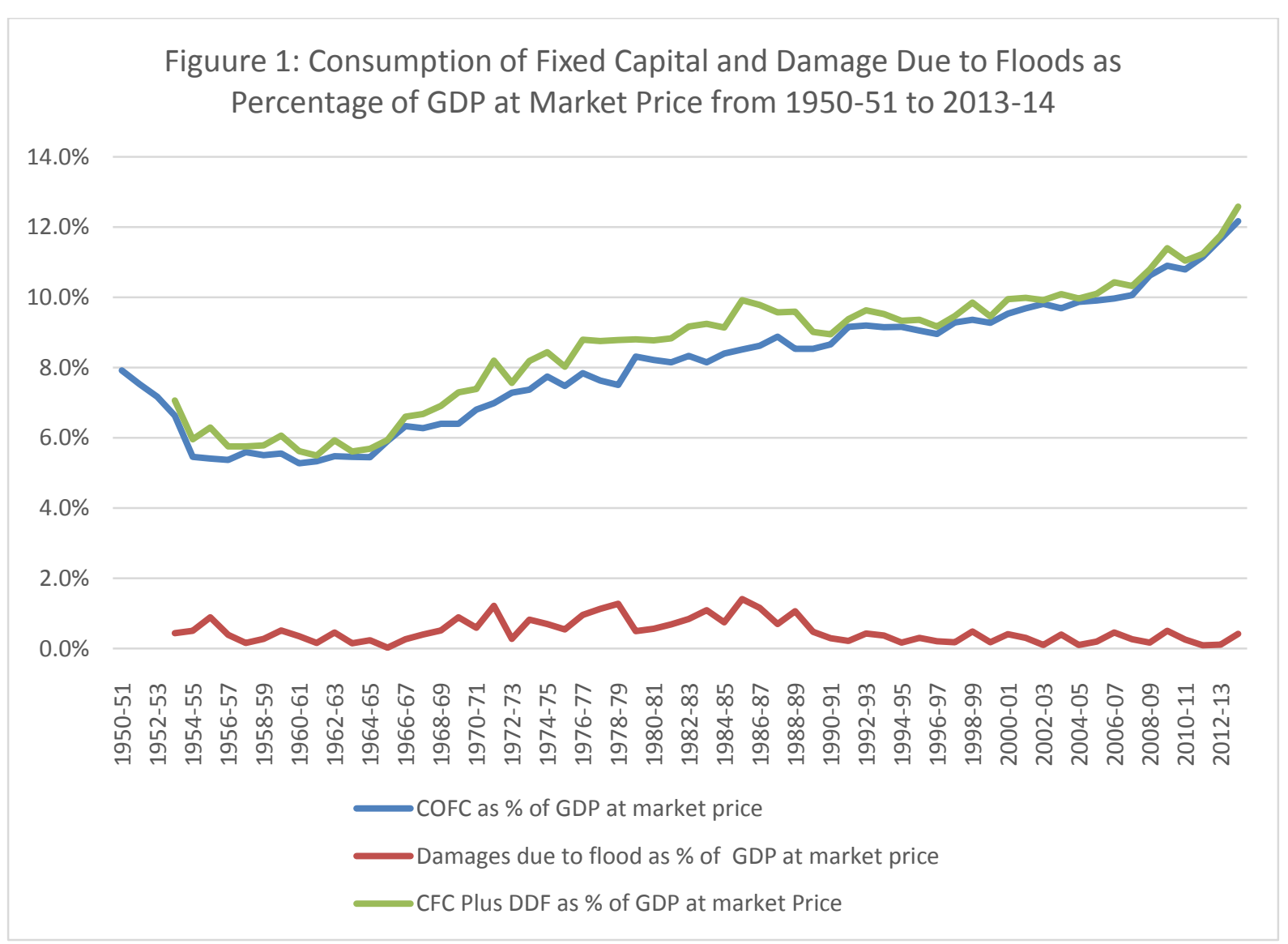


Table 4 presents the state wise per capita average annual loss due to floods and heavy rains. We do not find any consistent trend in this table, except, that smaller states have recorded maximum per capita loss due to floods and heavy rain falls. However, the loss due to floods and rains do not capture all losses due to many other natural disasters such as cyclones, earthquakes, landslides etc. It should be noted that weather related natural calamities such as cyclones and floods cause maximum damage compared to other disasters. Our objective is to assess the full economic cost of all disasters. But due to lack of systematic data in public domain we are not able to do so rather we rely upon indirect data sources to provide an indicative measurement.

\begin{tabular}{|c|c|c|c|c|}
\hline States & $\begin{array}{l}1997-98 \text { to } \\
2001-02\end{array}$ & $\begin{array}{l}2002-03 \text { to } \\
2006-07\end{array}$ & $\begin{array}{l}2007-08 \text { to } 2011- \\
12\end{array}$ & $\begin{array}{l}2012-13 \text { to } 2016- \\
17\end{array}$ \\
\hline $\begin{array}{l}\text { Andaman and } \\
\text { Nicobar } \\
\text { Islands }\end{array}$ & 0.0 & 0.0 & 0.0 & 2.3 \\
\hline $\begin{array}{l}\text { Andhra } \\
\text { Pradesh }\end{array}$ & 161.8 & 736.4 & 1243.2 & 193.6 \\
\hline $\begin{array}{l}\text { Arunachal } \\
\text { Pradesh }\end{array}$ & 17.4 & 12744.7 & 5832.4 & 7937.7 \\
\hline Assam & 71.4 & 86.8 & 4.7 & 203.2 \\
\hline Bihar & 45.9 & 114.3 & 55.7 & 16.7 \\
\hline Chandigarh & NA & 1.4 & 0.0 & 0.0 \\
\hline Chhattisgarh & 110.7 & 15.6 & 15.5 & 0.0 \\
\hline Delhi & 13.5 & 0.0 & 0.0 & 0.0 \\
\hline Goa & 5.2 & 0.5 & 3.8 & 0.8 \\
\hline Gujarat & 5.1 & 88.7 & 39.7 & 0.5 \\
\hline Haryana & 102.1 & 0.1 & 10.0 & 80.6 \\
\hline $\begin{array}{l}\text { Himachal } \\
\text { Pradesh }\end{array}$ & 971.6 & 533.5 & 1565.7 & 1171.9 \\
\hline $\begin{array}{l}\text { Jammu and } \\
\text { Kashmir }\end{array}$ & 22.1 & 0.0 & 0.0 & 1300.9 \\
\hline Jharkhand & 0.0 & 0.0 & 0.1 & 0.3 \\
\hline Karnataka & 4.1 & 183.3 & 887.1 & 164.1 \\
\hline Kerala & 89.8 & 1.3 & 49.9 & 70.2 \\
\hline $\begin{array}{l}\text { Madhya } \\
\text { Pradesh }\end{array}$ & 1.5 & 19.0 & 0.2 & 20.1 \\
\hline Maharashtra & 0.4 & 3.1 & 0.0 & 0.0 \\
\hline Manipur & 52.5 & 65.9 & 86.3 & 300.9 \\
\hline Meghalaya & 7.3 & 171.5 & 0.0 & 1012.1 \\
\hline Mizoram & NA & 0.0 & 0.0 & 4.0 \\
\hline Nagaland & $\mathrm{NA}$ & 0.0 & 0.0 & 64.3 \\
\hline Odisha & 115.1 & 199.3 & 331.0 & 14.8 \\
\hline Puducherry & 0.0 & 0.0 & 0.0 & 473.5 \\
\hline
\end{tabular}




\begin{tabular}{|c|c|c|c|c|}
\hline Punjab & 2.3 & 0.4 & 25.4 & 42.7 \\
\hline Rajasthan & 95.5 & 15.5 & 0.0 & 87.0 \\
\hline Sikkim & 0.4 & 0.1 & 0.0 & 1.0 \\
\hline Tamil Nadu & 3.1 & 2.2 & 0.5 & 0.2 \\
\hline Telangana & NA & $\mathrm{NA}$ & NA & NA \\
\hline Tripura & 72.9 & 23.2 & 14.6 & 210.5 \\
\hline Uttar Pradesh & 47.9 & 7.8 & 22.9 & 2.3 \\
\hline Uttarakhand & 0.0 & 0.0 & 0.0 & 7719.2 \\
\hline West Bengal & 236.8 & 33.0 & 31.4 & 561.6 \\
\hline
\end{tabular}

\subsection{Inferences from SDRF estimates}

Starting from 1999-2000, the Union government has been providing financial assistances to the states for mitigating the losses of natural disasters. As per the National Disaster Management Policy, the primary responsibility for disaster management rests with the States. The concerned State Governments undertake relief activities according to the magnitude of the ground situation, in the wake of notified natural disasters from the State Disaster Response Fund (SDRF) already placed at their disposal in accordance with Government of India approved items and norms without any discrimination. For calamity of a severe nature, additional assistance is supplemented by Government of India from the National Disaster Response Fund (NDRF) by following the laid down procedure.

The corpus of SDRF is contributed by the Government of India and the State Government in the ratio 75:25 for General Category States and 90:10 for Special Category States. NDRF is fully funded by the Government of India. Under the prevailing guidelines, the first charge of relief expenditure is always on the SDRF. Allocation of SDRF for the each State Government is done by the Finance Commission (set-up under the Article 280 of constitution from timeto-time), for the Award period. In addition, $10 \%$ of the annual fund allocation of the SDRF may be used for localized State specific natural disaster. No calamity-wise allocation is made under the SDRF to State.

The allocation to the SDRF by Finance Commission is done after a thorough assessment of the cost of disaster across states and consultation with the state governments. Therefore, analysis of allocation of SDRF to various states will provide an indicative scenario of the cost of disasters across states. Figure 2 presents the state wise SDRF allocation recommended by the Finance Commission XIV. Maharashtra state receives the maximum SDRF allocation followed by Rajasthan, Madhya Pradesh, Odisha and Gujarat. However we cannot compare the cost of disaster with the total sum of allocation because of the wide variation in the size of the states in terms of geography and population. Therefore, we should compare the per capita SDRF allocation. 


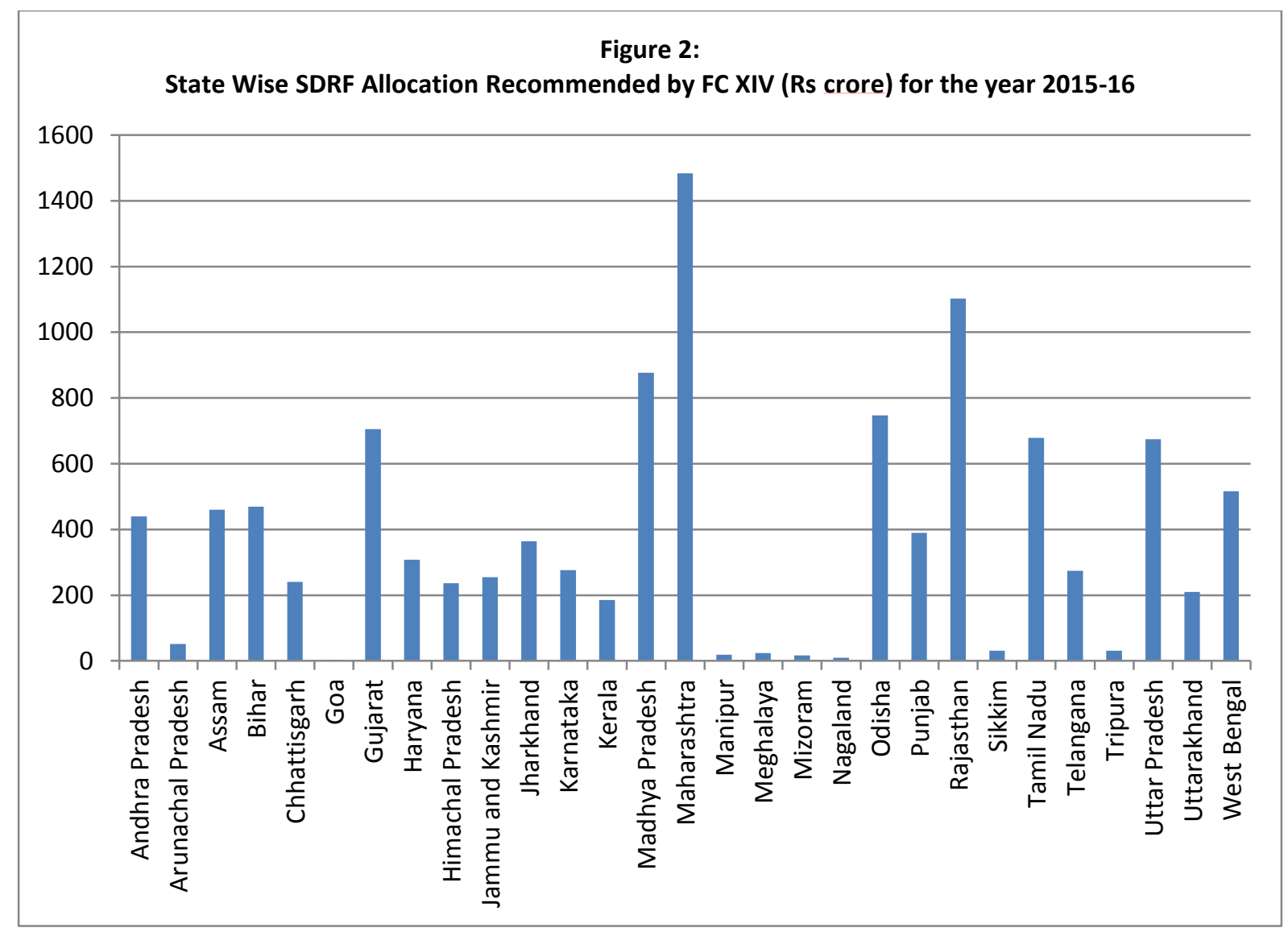

Figure 3 presents the per capita SDRF allocation to all states of India. Sikkim received the maximum per capita SDRF allocation from the fourteenth Finance Commission followed by Arunachal Pradesh, Himachal Pradesh and Uttarakhand. Among the major states Odisha has received the maximum per capita SDRF allocation in 2015-16. The all India average per capita SDRF allocation made is 91 rupees.

The financial assistance received by the state from the Union Government, however, falls short of the expenditure incurred by the states. Table 5 presents the relief expenditure of states as percentage of receipts for the period 2002-09. For most of the states and for most of the years, the relief expenditure far exceeds the receipt. The relief expenditure of states ranges from $22 \%$ of the receipts (West Bengal) to $540 \%$ for Bihar in some years. This implies that for maximum number of states, the relief expenditure incurred falls short of the receipt of assistance from the Union Government. The relief expenditure, however, does not reflect the actual cost of the disaster. Most of the states submit a memorandum to the Union Government and Finance Commission of India with the estimated economic loss due to different natural disasters and demand financial assistance from the same. In response to such demands the Union Government releases money to the states. However, the financial assistance provided by the Union government is far less than the demand placed by the states (NIDM, 2009).

Table 5: Relief Expenditure as Percentage of Receipts

\begin{tabular}{|r|l|r|r|r|r|r|r|r|r|}
\hline & \multicolumn{1}{|c|}{$\begin{array}{c}\text { 2002- } \\
\mathbf{0 3}\end{array}$} & $\begin{array}{c}\text { 2003- } \\
\mathbf{0 4}\end{array}$ & \multicolumn{1}{c|}{$\begin{array}{c}\text { 2004- } \\
\mathbf{0 5}\end{array}$} & $\begin{array}{c}\text { 2005- } \\
\mathbf{0 6}\end{array}$ & $\begin{array}{c}\text { 2006- } \\
\mathbf{0 7}\end{array}$ & $\begin{array}{c}\text { 2007- } \\
\mathbf{0 8}\end{array}$ & $\begin{array}{c}\text { 2008- } \\
\mathbf{0 9}\end{array}$ & Average \\
\hline 1 & $\begin{array}{l}\text { Andhra } \\
\text { Pradesh }\end{array}$ & 256 & 34 & 237 & 120 & 145 & 116 & 144 & 150.3 \\
\hline 2 & $\begin{array}{l}\text { Arunachal } \\
\text { Pradesh }\end{array}$ & 101 & 100 & 101 & 100 & 98 & 100 & 99 & 99.9 \\
\hline
\end{tabular}




\begin{tabular}{|r|l|r|r|r|r|r|r|r|r|}
\hline 3 & Bihar & 89 & 113 & 37 & 5 & 21 & 540 & 40 & 120.7 \\
\hline 4 & Chhattisgarh & 111 & 123 & 70 & 42 & 62 & 166 & 76 & 92.9 \\
\hline 5 & Gujrat & 213 & 137 & 91 & 69 & 160 & 146 & 130 & 135.1 \\
\hline 6 & Haryana & 93 & 9 & 21 & 72 & 80 & 115 & 57 & 63.9 \\
\hline 7 & Himachal & 100 & 100 & 100 & 100 & 100 & 100 & 100 & 100.0 \\
\hline 8 & Karnataka & 69 & 90 & 156 & 80 & 192 & 105 & 102 & 113.4 \\
\hline 9 & Kerala & 60 & 100 & 57 & 119 & 96 & 133 & 76 & 91.6 \\
\hline 10 & Madhya & 129 & 189 & 133 & 66 & 71 & 192 & 99 & 125.6 \\
\hline 11 & Pradesh & 100 & 188 & 74 & 107 & 245 & 96 & 129 & 134.1 \\
\hline 12 & Maharashtra & 100 & 114 & & 253 & 0 & 95 & 89.7 \\
\hline 13 & Meghalaya & 74 & 58 & 26 & 116 & 23 & 41 & 57 & 56.4 \\
\hline 14 & Mizoram & 100 & 100 & 100 & 100 & 100 & 100 & 100 & 100.0 \\
\hline 15 & Orissa & 152 & 130 & 148 & 79 & 111 & 136 & 117 & 124.7 \\
\hline 16 & Rajasthan & 94 & 87 & 40 & 88 & 121 & 72 & 87 & 84.1 \\
\hline 17 & Sikkim & 113 & 73 & 98 & 79 & 163 & 100 & 102 & 104.0 \\
\hline 18 & Tamil & 190 & 224 & 206 & 224 & 163 & 284 & 210 & 214.4 \\
\hline 19 & Tripura & 70 & 58 & 125 & 38 & 21 & 193 & 51 & 79.4 \\
\hline 20 & Uttarakhand & 387 & - & 100 & - & 100 & - & 114 & 175.3 \\
\hline & Uttar & 123 & 47 & 77 & 23 & 15 & 187 & 65 & 76.7 \\
\hline 21 & Pradesh & 22 & 43 & 39 & 49 & 124 & 241 & 65 & 83.3 \\
\hline 22 & West Bengal & 25 & & & & & & \\
\hline
\end{tabular}

In absence of the latest data, we have used the data available in a research report submitted by the National Institute of Disaster Management, (NIDM, 2009) to the $13^{\text {th }}$ Finance Commission of India. In this report NIDM had compiled the data provided by the state governments in their memorandum to the $13^{\text {th }}$ Finance Commission on the demand for financial assistance for natural disasters during 2000-01 to 2008-09. The disasters included, flood, cyclone, hailstorm, and drought. We took the GSDP and NSDP data for all major states from the RBI's Hand Book of Statistics on Indian States. We used the GSDP and NSDP data in 2004-05 constant price for the period 2000-09. The economic losses due to natural disasters were obtained from the NIDM (2009) report. We used GDP deflator to convert the economic loss due to disasters into 2004-05 constant prices. Using 2001 census data and the economic loss due to disaster we calculated average per capita cost of disaster for the period 2000-09. Similarly, we have also calculated the average per capita NSDP for the period 2000-09 and per capita disaster cost adjusted NSDP (Per capita NSDP minus per capita economic cost due to natural disaster). At the end we have also estimated per capita disaster cost as a percentage of per capita NSDP (Table 6). Arunachal Pradesh witnesses the maximum per capita cost of disaster as percentage of per capita NSDP $(6.8 \%)$ followed by Jammu and Kashmir (3.5\%), Bihar (3.1\%) and Himachal Pradesh (2.7\%). 14 states have reported more than $1 \%$ of per capita NSDP as cost of disaster. 
Table 6: Per Capita NSDP, Cost of Disaster and NSDP adjusted for the Cost of Disaster

\begin{tabular}{|c|c|c|c|c|}
\hline State & $\begin{array}{l}\text { Per Capita } \\
\text { Cost of } \\
\text { Disaster }\end{array}$ & $\begin{array}{l}\text { Per Capita } \\
\text { NSDP }\end{array}$ & $\begin{array}{l}\text { Per capita } \\
\text { Disaster Cost } \\
\text { adjusted NSDP }\end{array}$ & $\begin{array}{l}\text { Per Capita } \\
\text { Disaster Cost } \\
\text { as \% of Per } \\
\text { Capita NSDP }\end{array}$ \\
\hline Andhra Pradesh & 156.3 & 16433.1 & 16276.8 & $1.0 \%$ \\
\hline Arunachal Pradesh & 1951.2 & 28678.7 & 26727.4 & $6.8 \%$ \\
\hline Assam & 205.3 & 17684.8 & 17479.5 & $1.2 \%$ \\
\hline Bihar & 267.7 & 8717.9 & 8450.1 & $3.1 \%$ \\
\hline Chhattisgarh & 161.9 & 20308.2 & 20146.3 & $0.8 \%$ \\
\hline Gujarat & 501.0 & 35542.1 & 35041.1 & $1.4 \%$ \\
\hline Haryana & 109.3 & 42162.5 & 42053.2 & $0.3 \%$ \\
\hline Himachal Pradesh & 960.1 & 35514.7 & 34554.6 & $2.7 \%$ \\
\hline Jammu and Kashmir & 808.8 & 23296.8 & 22488.0 & $3.5 \%$ \\
\hline Jharkhand & 139.9 & 18372.2 & 18232.4 & $0.8 \%$ \\
\hline Karnataka & 358.1 & 30119.2 & 29761.1 & $1.2 \%$ \\
\hline Kerala & 292.3 & 33989.3 & 33697.0 & $0.9 \%$ \\
\hline Madhya Pradesh & 123.1 & 17229.1 & 17106.0 & $0.7 \%$ \\
\hline Maharashtra & 226.2 & 41261.6 & 41035.5 & $0.5 \%$ \\
\hline Manipur & 198.3 & 19785.4 & 19587.2 & $1.0 \%$ \\
\hline Meghalaya & 101.8 & 25921.9 & 25820.0 & $0.4 \%$ \\
\hline Mizoram & 626.5 & 28185.9 & 27559.4 & $2.2 \%$ \\
\hline Nagaland & 16.4 & 28429.9 & 28413.4 & $0.1 \%$ \\
\hline Odisha & 214.8 & 18536.5 & 18321.7 & $1.2 \%$ \\
\hline Punjab & 202.5 & 36952.2 & 36749.7 & $0.5 \%$ \\
\hline Rajasthan & 371.4 & 20684.0 & 20312.7 & $1.8 \%$ \\
\hline Sikkim & 447.4 & 28597.9 & 28150.6 & $1.6 \%$ \\
\hline Tamil Nadu & 427.8 & 33723.0 & 33295.2 & $1.3 \%$ \\
\hline Tripura & 26.2 & 25984.6 & 25958.4 & $0.1 \%$ \\
\hline Uttar Pradesh & 128.4 & 14392.7 & 14264.3 & $0.9 \%$ \\
\hline Uttarakhand & 156.7 & 28453.3 & 28296.7 & $0.6 \%$ \\
\hline West Bengal & 0.0 & 24248.9 & 24248.9 & $0.0 \%$ \\
\hline \multicolumn{5}{|c|}{$\begin{array}{l}\text { Source: Calculated from the Demand submitted by states to the Finance Commission and compiled } \\
\text { by National Institute of Disaster Management in NIDM (2009) "FINANCING DISASTER MANAGEMENT IN } \\
\text { INDIA: A Study for the Thirteenth Finance Commission". National Institute of Disaster Management. August } \\
2009 \text {. } \\
\text { Note: All Per Capita estimates are the average estimates of the specific indicator in 2004-05 constant price for } \\
\text { the period 2000-01 to 2008-09 }\end{array}$} \\
\hline
\end{tabular}

The money spent on the mitigation of disasters could have been invested in either new productive investment. Therefore, the part of expenditure incurred on disaster mitigation should be considered as leakages from productive expenditure of the government. Figure 4 shows the SDRF allocation as a percentage of the total expenditure of the states for the year 2015-16. At all India level the total SDRF allocation amounts to $0.5 \%$ of the total expenditure (TE). For Assam this amounts to $1.2 \%$ of State Total Expenditures (STE), followed by Odisha ( $1 \%$ of STE), Arunachal Pradesh ( $0.9 \%$ of STE), Uttarakhand ( $0.8 \%$ of STE) 
Figure 3: State Wise Per capita SDRF for the year 2015-16

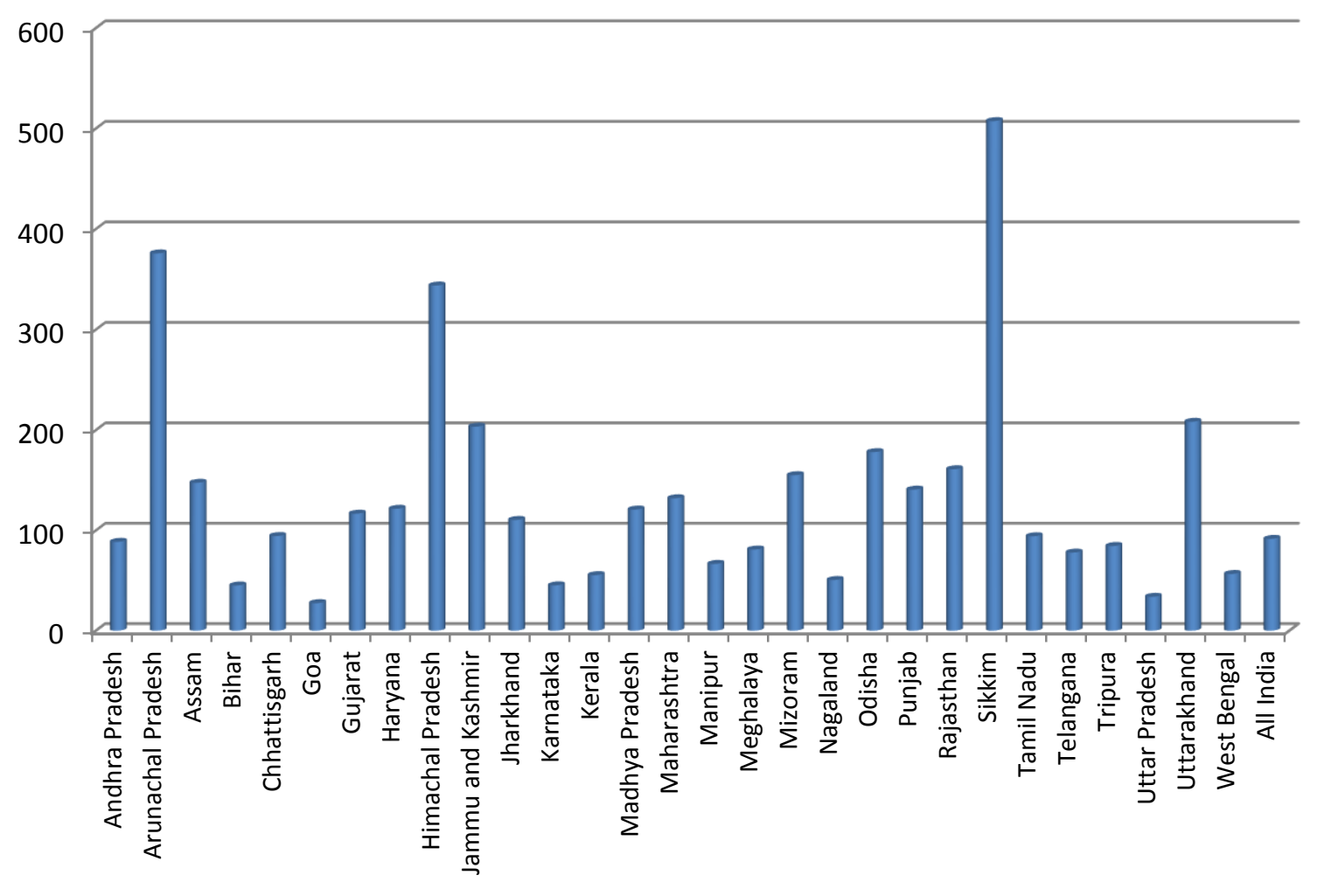

Figure 3: SDRF as a percentage of Total Expenditure of the State for the year 2015-16

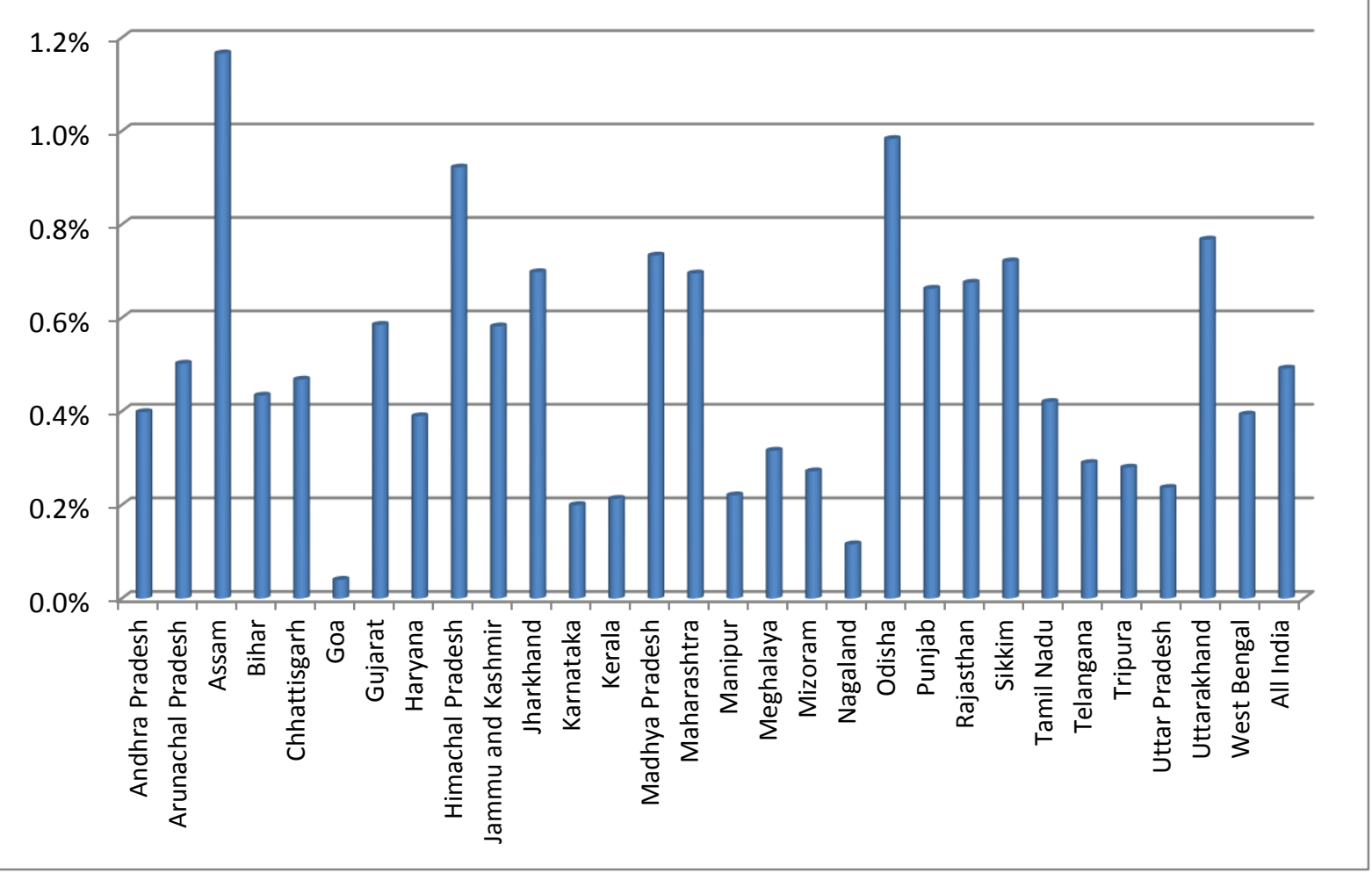




\subsection{Case Study of Odisha}

Odisha faces maximum number of tropical cyclones. After the devastation made by 1999 super cyclone, the state government has been maintaining systematic data to quantify the total economic loss due to cyclones only. The financial losses due to disasters are much higher than the relief expenditure incurred by the state. Therefore, the state wise SDRF allocation will be a gross underestimation of the actual financial losses accrued to the state and individuals. Figure 5 shows the financial loos due to natural disaster and relief expenditure incurred by Odisha. Barring a few years, the relief expenditure has always remained much below the financial loss. Relief expenditure as a percentage of the total financial loss has ranged from the lowest three percent to highest 374\%. Between 1994-95 and 2013-14, only in three years the relief expenditure has exceeded the assessed financial loss. In rest 15 years for which data are available total relief expenditure has remained far below the assessed financial losses. This clearly shows that use of SDRF allocation to quantify the financial losses due to disasters is a gross underestimation. However, due to unavailability of systematic data we are using this data for getting only indicative scenario.

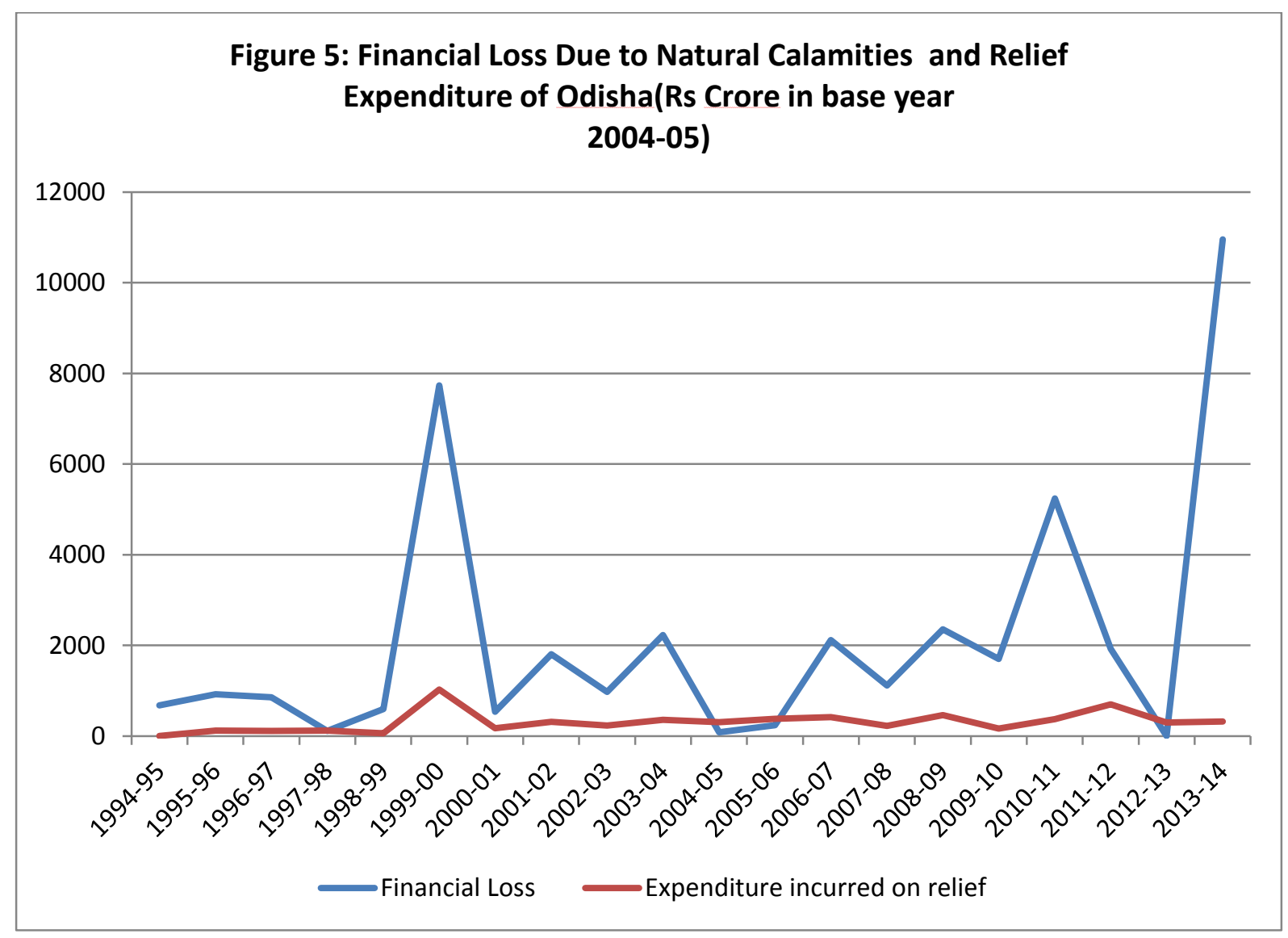

Since our primary objective is to compute the Net Domestic Product adjusted for the depreciation caused due to natural disasters it is important to compute the economic loss due to natural disaster as a percentage of GSDP. Figure 6 presents the economic loss as a percentage of GSDP. During major cyclones the economic loss shoots up very high. In 1999 the economic cost of super cyclone was as high as 13\% of GSDP and in 2013 the economic cost of Phailin was eight percentage of GSDP. In most other years the cost of natural disasters in Odisha has been estimated between one to four percentage of GSDP. Thus for Odisha, the depreciation due to natural disaster has widely varied from as low as one percent to $13 \%$ of GSDP. This has huge negative implications for the welfare of the state. Out of one rupee earned by the state one to 13 paisa is spent every year just to remain at the same level. 


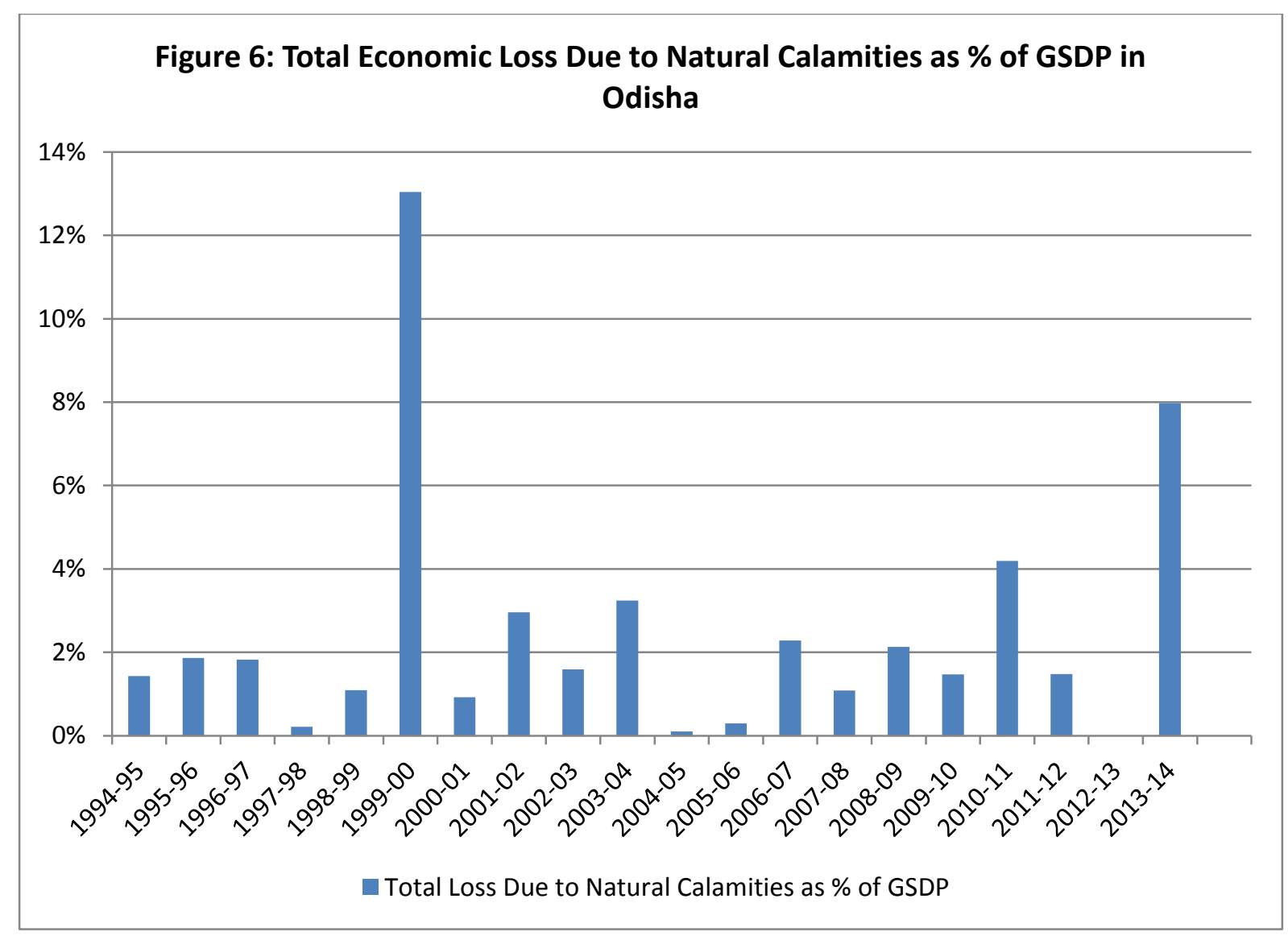

In order to know the implications of natural disaster on the investment we had discussed in earlier section that a large amount of money is spent for repairing and reconstruction of the same physical capital. Therefore, the amount of productive investment declines signifincatly in the states that face natural disasters. Figure 7 shows the financial losses due to natural disaster and relief expenditure as a percentage of the total expenditure of the state. The total economic losses as a percentage of GSDP of Odisha varies widely from a low of one percent to the highest level of 44 percent during the period 1994-95 and 2013-14. During this period, in maximum years the economic loss due to natural disaster as a percentage of GSDP has remained around 10 percent. In spite of this high level of economic losses, the expenditure of the state on relief has remained very low. The total expenditure of Odisha on relief as a percentage of total expenditure of the state has mostly remained between one to two percent. Only during super cyclone of 1999 this share had reached five percent. This has dampening effect on the capability of the state and individuals. When the economic losses due to natural disaster is very high but the state fails to adequately compensate the losses, it may have wide ranging effects on the economy. In case of damage of public utilities, like roads, electricity, cold storage, drinking water, industries, without adequate expenditure on the repairing and reconstruction, this will not only affect the quality of life but also discourage the private investment. This may also ruin the Micro, Small and Medium scale industries. There are evidences that after 1999 super cyclone the MSME sector was worst hit. The film theatres in rural parts of Odisha were completely destroyed during this cyclone and they could never come back to operation ${ }^{1}$. As a result of which the Odia film industry has been suffering from low level of equilibrium trap. In the extremely sever cyclone Fani, in May 2019 Raghurajpur village, which is famous for Patachitra arts has been completely devastated. Hundreds of

\footnotetext{
${ }^{1}$ https://www.telegraphindia.com/states/odisha/state-s-first-cinema-in-ruins-sri-sitaram-vilas-talkies-fails-torise-after-super-cyclone-blow/cid/431548
} 
households in this village who depended upon the art have lost their income source ${ }^{2}$. Without adequate relief to these households, it may not be possible to restart their business.

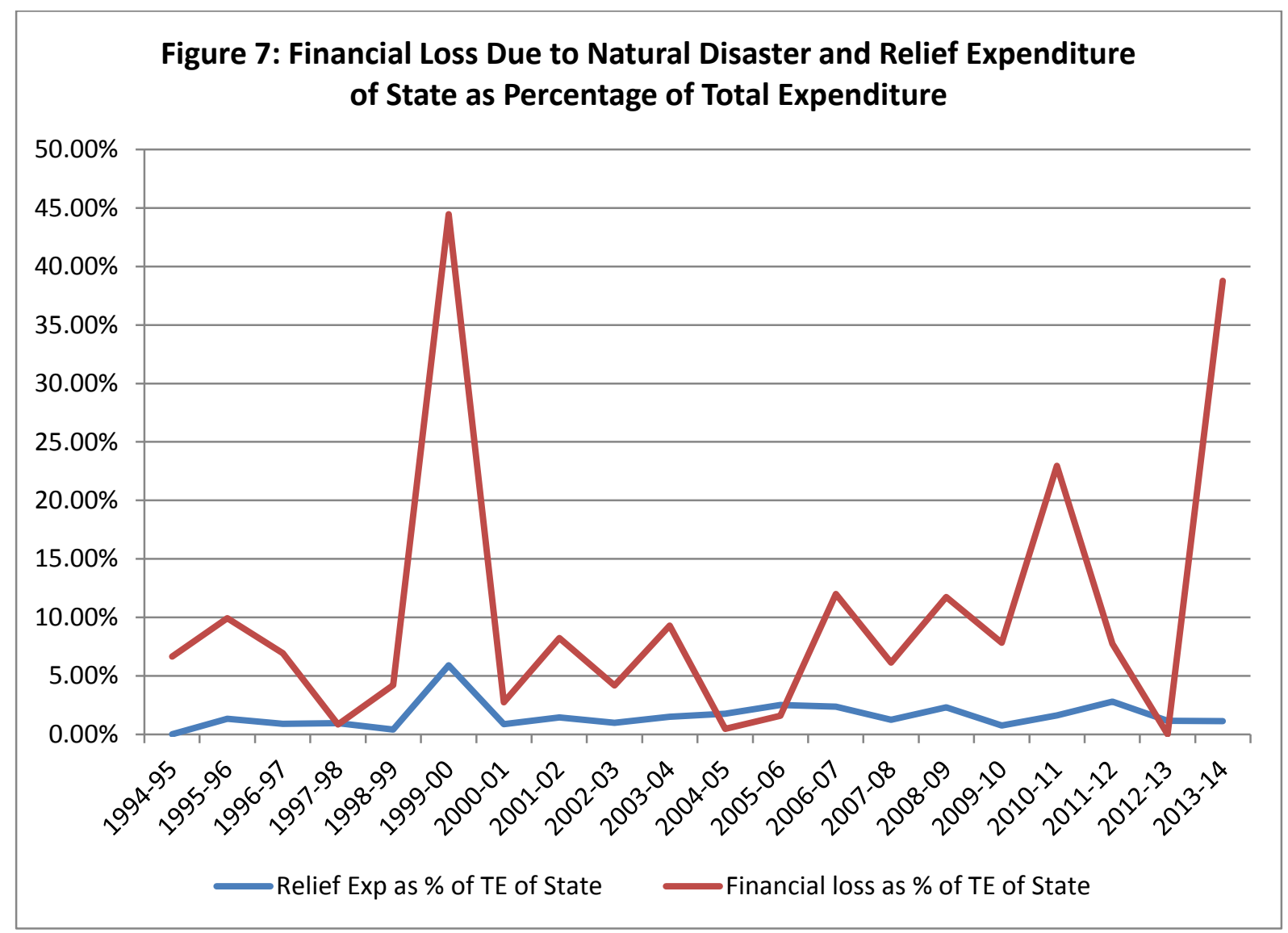

\subsection{Natural Disaster Adjusted NSDP for Odisha}

Table 7 presents the Natural Calamity Adjusted NDP for Odisha for the period 1994-95 to 2013-14.

\footnotetext{
${ }^{2}$ https://economictimes.indiatimes.com/news/politics-and-nation/after-the-storm-odisha-village-picks-uppieces-after-cyclone-fani/articleshow/69322984.cms
} 


\begin{tabular}{|c|c|c|c|c|c|c|c|c|c|c|}
\hline Year & $\begin{array}{l}\text { GSDP At } \\
\text { Current } \\
\text { Prices }\end{array}$ & $\begin{array}{l}\text { GSDP At } \\
2004-05 \\
\text { prices }\end{array}$ & $\begin{array}{l}\text { NSDP At } \\
\text { Current } \\
\text { Prices }\end{array}$ & $\begin{array}{l}\text { NSDP At } \\
2004-05 \\
\text { prices }\end{array}$ & $\begin{array}{l}\text { Financial } \\
\text { Loss Due } \\
\text { to Natural } \\
\text { Disaster } \\
\text { (Current } \\
\text { Price) } \\
\end{array}$ & $\begin{array}{l}\text { Financial } \\
\text { Loss due } \\
\text { to Natural } \\
\text { Disaster } \\
\text { (in 2004- } \\
05 \text { price) } \\
\end{array}$ & $\begin{array}{l}\text { Disaster } \\
\text { adjusted } \\
\text { NSDP } \\
\text { (current } \\
\text { price) }\end{array}$ & $\begin{array}{l}\text { Disaster } \\
\text { adjusted } \\
\text { NSDP } \\
2004-05 \\
\text { price }\end{array}$ & $\begin{array}{l}\text { Percapita } \\
\text { Disaster } \\
\text { adjusted } \\
\text { NSDP in } \\
\text { current } \\
\text { Prices } \\
\end{array}$ & $\begin{array}{l}\text { Percapita } \\
\text { Disaster } \\
\text { adjusted } \\
\text { NSDP in } \\
2004-05 \\
\text { Prices }\end{array}$ \\
\hline & \multicolumn{8}{|c|}{ Rupees Lakh } & \multicolumn{2}{|c|}{ Rupees } \\
\hline 1994-95 & 2637803 & 4728488 & 2227992 & 4009160 & 37653 & 67496.23 & 2190339 & 3941664 & 6521.88 & 11737.02 \\
\hline $1995-96$ & 3200294 & 4923531 & 2712473 & 4164616 & 59772 & 91956.96 & 2652701 & 4072659 & 7777.74 & 11941.37 \\
\hline 1996-97 & 3162811 & 4684672 & 2633170 & 3913538 & 57700 & 85463.71 & 2575470 & 3828074 & 7439.32 & 11058.12 \\
\hline $1997-98$ & 3830064 & 5311965 & 3214665 & 4464813 & 8092 & 11222.9 & 3206573 & 4453590 & 9130.96 & 12682.04 \\
\hline 1998-99 & 4255150 & 5462975 & 3582055 & 4592379 & 46410 & 59583.49 & 3535645 & 4532796 & 9929.66 & 12730.66 \\
\hline 1999-00 & 4789168 & 5932446 & 4314452 & 5372881 & 624396 & 773452.8 & 3690056 & 4599428 & 10207.81 & 12722.49 \\
\hline 2000-01 & 4841484 & 5830376 & 4325303 & 5223400 & 44523 & 53617 & 4280780 & 5169783 & 11688.43 & 14116.60 \\
\hline 2001-02 & 5170371 & 6110766 & 4590332 & 5448028 & 153088 & 180931.9 & 4437244 & 5267096 & 11967.12 & 14205.02 \\
\hline 2002-03 & 5480111 & 6105838 & 4873028 & 5432171 & 87140 & 97089.77 & 4785888 & 5335081 & 12761.65 & 14226.11 \\
\hline 2003-04 & 6610014 & 6889860 & 5855462 & 6078415 & 214183 & 223250.8 & 5641279 & 5855164 & 14876.20 & 15440.29 \\
\hline 2004-05 & 7772943 & 7772943 & 6798702 & 6798702 & 8120 & 8120 & 6790582 & 6790582 & 17628.92 & 17628.92 \\
\hline 2005-06 & 8509649 & 8214472 & 7354959 & 7100497 & 25218 & 24343.25 & 7329741 & 7076154 & 18781.38 & 18131.62 \\
\hline 2006-07 & 10183947 & 9270083 & 8792126 & 7984484 & 232243 & 211402.5 & 8559883 & 7773081 & 21649.62 & 19659.33 \\
\hline 2007-08 & 12927445 & 10284562 & 11110925 & 8669191 & 140023 & 111396.7 & 10970902 & 8557794 & 27385.48 & 21361.93 \\
\hline 2008-09 & 14849071 & 11081178 & 12751620 & 9320665 & 315781 & 235652.8 & 12435839 & 9085012 & 30638.02 & 22382.43 \\
\hline 2009-10 & 16294643 & 11585113 & 13583679 & 9395723 & 239116 & 170005.9 & 13344563 & 9225717 & 32447.59 & 22432.63 \\
\hline 2010-11 & 19752990 & 12513105 & 16476038 & 9987972 & 827776 & 524378.7 & 15648262 & 9463593 & 37550.59 & 22709.65 \\
\hline 2011-12(3rd & 22058927 & 13011301 & 18352151 & 10362763 & 326538 & 192606.1 & 18025613 & 10170157 & 42689.67 & 24085.86 \\
\hline 2012-13(2nd & 25122046 & 13501017 & 21062228 & 10766375 & \#VALUE! & \#VALUE! & \#VALUE! & \#VALUE! & \#VALUE! & \#VALUE! \\
\hline $2013-14(1 \mathrm{st}$ & 27297992 & 13746828 & 22787686 & 10808072 & 2176600 & 1096101 & 20611086 & 9711971 & 47538.70 & 22400.86 \\
\hline 2014-15 & 31081024 & 14857608 & 26022195 & 11656558 & & & & & & \\
\hline
\end{tabular}




\section{Conclusion}

The frequency of natural disasters and the extent of damages are showing increasing trend in recent years. Per capita GDP or NDP numbers are used as assess the level of wellbeing and backwardness of states. These are also used for fiscal transfer in India. Per capita NDP calculation accounts for the depreciation of physical capital due to wearing and tearing effect. However, the conventional measures of Consumption of Fixed Capital do not include the damage of capital due to natural disaster. However, when the damage to physical capital due to natural disaster is substantial, it has significant implications for welfare of the people and economic growth of the state. If a state suffers massive damage to physical infrastructure due to natural disaster on regular interval, it will definitely reduce its capability to achieve fast economic growth and reduce poverty. Therefore, the damage to physical infrastructures caused by natural disasters should be accounted for in the NDP calculations. In this paper we have provided a framework for this purpose and provided the natural disaster adjusted NDP estimates for the state Odisha.

\section{References}

Benson, C. and Clay, E.J.(2004). Understanding the Economic and Financial Impacts of Natural Disasters. Disaster Risk Management Series, The World Bank, Washington, D.C.

Cuaresma, J.C.(2009). Natural Disasters and Human Capital Accumulation. Policy Research Working Paper 4862, The World Bank.

Central Statistical Office, India (2012). National Accounts Statistics: Sources and Methods 2012.Retrieved from http://mospi.nic.in/sites/default/files/publication_reports/sources_method_2012\%20(1).pdf

Das, S. (2012). The role of natural ecosystems and socio-economic factors in the vulnerability of coastal villages to cyclone and storm surge. Nat Hazards , 64, 531-546.

Das, S (2016). Economics of Natural Disasters in Odisha. In P.B. Nayak, S.C.Panda \& P.K Pattanaik(Eds.), The Economy of Odisha: A Profile (pp. 266-300). New Delhi: Oxford University Press.

Domar, Evsey (1946). "Capital Expansion, Rate of Growth, and Employment". Econometrica. 14 (2): 137-147. doi: $10.2307 / 1905364$.

Gaddis, B. E., Miles, B., Morse, S., \& Lewis, D. (2007). Full-cost accounting of coastal disasters in the United States: Implications for planning and preparedness. Ecological Economics , 63, 307-318.

Guha-Sapir D, Hargitt D and Hoyois P (2004) Thirty Years of Natural Disasters 1974-2003: The numbers. Centre for research on the Epidemiology of Disasters (CRED). Louvain-laNeuve, Belgium: Presses universitaires de Louvain.

Hallegatte, S., Hourcade, J.-C., \& Dumas, P. (2007). Why economic dynamics matter in assessing climate change damages: Illustration on extreme events. Ecological Economics, 62, 330-340. 
Hallagatte, S. and Dumas, P. (2009). Can natural disasters have positive consequences? Investigating the role of embodied technical change. Ecological Economics, 68, 777-786.

Hallegatte, S., \& Przyluski, V. (2010). The Economics of Natural Disasters. The World Bank , 5507.

Jonkman, S.N., Bockarjova, M., Kok,M., Bernardini, P. (2008). Integrated hydrodynamic and economic modelling of flood damage in the Netherlands. Ecological Economics, 66, 77-90.

Kadekodi, G.K.(2001). Environment and Development. In R.N. Bhattacharya (Eds.), Environmental Economics: An Indian Perspective (pp. 162-217). New Delhi: Oxford University Press.

National Statistical Organisation. (2013). Green National Accounts in India: A Framework. Retrieved from http://www.mospi.gov.in/sites/default/files/publication_reports/Green_National_Accouts_in_ India_1may13.pdf

NCRMP (2019) Cyclones and their Impact in India. National Cyclone Risk Mitigation Project, Govt. of India. https://ncrmp.gov.in/cyclones-their-impact-in-india

NIDM (2009) "FINANCING DISASTER MANAGEMENT IN INDIA: A Study for the Thirteenth Finance Commission". National Institute of Disaster Management. August 2009.

Noy, I. (2008). The macroeconomic consequences of disasters. Journal of Development Economics, 88, 221-231.

Parida, Yashobanta. (2020). Economic impact of floods in the Indian states. Environment and Development Economics, 25(3), 267-290. doi:10.1017/S1355770X19000317.

Parida, Y., Agarwal Goel, P., Roy Chowdhury, J. et al. Do economic development and disaster adaptation measures reduce the impact of natural disasters? A district-level analysis, Odisha, India. Environ Dev Sustain (2020). https://doi.org/10.1007/s10668-020-00728-8.

Raddatz, C. (2009). The Wrath of God: Macroeconomic Costs of Natural Disasters. Policy Research Working Paper 5039, World Bank.

Rasmussen, N. T. (2004). Macroeconomic Implications of Natural Disasters in the Caribbean. IMF Working Paper, 04, 224.

Shabnam, N. (2014). Natural Disasters and Economic Growth: A Review. Int J Disaster Risk Sci, 05, 157-163. 